\title{
Complex Inter-Orthodox and Ecumenical Dialogue Following the Ukrainian Tomos of Autocephaly
}

\author{
Coriolan MureŞAN ${ }^{*}$
}

On the $6^{\text {th }}$ of January 2019 the Ecumenical Patriarch Bartholomew of Constantinople has handed over the Tomos of Autocephaly to Metropolitan Epiphany of the new Orthodox Church of Ukraine. Patriarch Bartholomew presented the document at a celebration on January 6, after signing it during a ceremony the previous day. The Patriarch urged the new Church in Ukraine to strive for unity and peace with believers who remain under the jurisdiction of the Moscow Patriarchate and to help them understand that Ukraine deserves a united Church body. At the January 5 signing ceremony, Bartholomew said that Ukrainians could now enjoy the sacred gift of emancipation, independence, and self-governance, becoming free from every external reliance and intervention.

With the official enthronement ceremony on February 3, 2019, Metropolitan Epiphany became the new Primate of the Orthodox Church of Ukraine. This marked the end of the process of establishing the autocephalous Ukrainian Orthodox Church, officially called the Orthodox Church of Ukraine. In the first few months of 2019 different parishes, which previously had been under the Moscow Patriarchate, chose to come under the jurisdiction of the new Church. The number of these parishes is significant, but does not represent at the moment more than around $15 \%$ of the parishes that are under the Moscow jurisdiction.

\section{Orthodox Reactions after the Tomos}

Except for the Ecumenical Patriarchate, no Orthodox Church has yet recognized the new Church of Ukraine even if the attitude of the different Churches is significantly different.

About 30 theologians and intellectuals from Georgia have conveyed greetings to Metropolitan of the Orthodox Church of Ukraine, Epiphany, on the occasion of the receipt of the Tomos of Autocephaly and enthronement. "Full of friendly, fraternal or sincere love for Christ [...] we sincerely celebrate the autocephaly of the Holy Orthodox Church of Ukraine and the

\footnotetext{
* Fr. Dr. Coriolan Mureșan, Greek-Catholic Church Dublin, Presbitery 2, Saint Josef Road, Dublin, (0035) 312447995, coryolan26@yahoo.it
} 
long-awaited spiritual and administrative independence of the exhausted Ukrainian parishes", ${ }^{1}$ the letter reads. Georgian theologians, "as children of the Georgian Apostolic Autocephalous Orthodox Church, (...) taking into account professional good conscience", ${ }^{2}$ declared that the legal process of granting the Tomos to the Orthodox Church of Ukraine had been conducted "in objective precision, in accordance with God-inspired canonical norms, in full preservation of the gospel principles and the rules of the holy fathers". ${ }^{3}$ The signatories of the letter also expressed hope that in the near future the Georgian church will reunite in Eucharistic communion with the Ukrainian church. The letter was signed by Georgian theologians Giorgi Tiginashvili, Zviad Tsabadze, Lado Narsiya, Beka Mindiashvili, Gocha Barnovi, Guram Lursmanashvili, David Tinikashvili, Lado Tsitlidze, Giorgi Geguchadze, Giorgi Nadirashvili, Dato Nebiyeridze, Nikoloz Gongadze, Vano Shoshiashvili, Sandro Khadzhaliya, Besarion Liparteliani, Vladimer Chikobava, Sergei Shoniya, Levan Zivzivadze, Mikheil Papashvili, Irakli Kikacheishvili, teacher of theological subjects Otar Skhidadze, master of Christian philosophy Besik Mashava, student of the fourth year of study at Tbilisi Spiritual Seminary Rati Biginashvili, analyst Gocha Mirtskhulava, political scientist Bakar Nadaraya, art expert Rostom Kachakhidze, and church parishioner Irina Dzadzamiya. The Georgian Orthodox Church has not recognized yet the new Church despite this reaction of the 30 theologians and intellectuals. The only official reaction in this case could be that of the Synod of the Georgian Orthodox Church.

On Thursday, February 21, 2019, the Synod of the Romanian Orthodox Church held its working session at the Synodal Hall of the Patriarchal Residence, under the chairmanship of Patriarch Daniel, and regarding the ecclesiastical situation in Ukraine, the Synod stressed that: "For almost thirty years, the issue of the Ukrainian schism was not solved, nor was any appeal made for a pan-Orthodox mediation, as was the case in the past with the schism in Bulgaria. Noticing this deadlock in resolving the situation, the Ecumenical Patriarchate granted the Tomos of Autocephaly to the hierarchs, clergy, and believers who were in schism with the Russian Orthodox Church and the entire Orthodoxy, but this Tomos was accepted only by the Ukrainian Orthodox people who were not in communion with the Moscow Patriarchate. Therefore, the problem of Ukrainian ecclesiastical unity

\footnotetext{
1 See the entire Letter of Congratulation: https://www.ukrinform.net/rubric-society/ 2633612-about-30-theologians-intellectuals-from-georgia-convey-greetings-to-epiphanius. html, viewed on March 13, 2019.

2 Ibidem.

3 Ibidem.
} 
is not fully resolved at present, also because in Ukraine there is a large Russian population having a direct relation to the Moscow Patriarchate". ${ }^{4}$ The Romanian Orthodox Church speaks about "schism with the entire Orthodoxy", and believes only the "Ukrainian Orthodox people who were not in communion with the Moscow Patriarchate" accepted the Tomos which is very debatable, even if at least one Bishop, different priests and hundreds of parishes under the jurisdiction of the Moscow Patriarchate joined the new Church. Speaking about the large Russian population having a direct relation to the Moscow Orthodoxy in Ukraine is again a matter of interpretation because the majority of the Orthodox under the jurisdiction of Moscow in Ukraine is Ukrainian (including the Bishops and the clergy). Once again, the Romanian Orthodox Church recommends that "through dialogue, the Ecumenical Patriarchate and the Moscow Patriarchate identify a solution to this ecclesiastical dispute by preserving the unity of faith, by respecting the administrative and pastoral freedom of the clergy and faithful in this country (including the right to autocephaly), and by restoring Eucharistic communion. In the event of an unsuccessful bilateral dialogue, it is necessary to convene a Synaxis of all Primates of Orthodox Churches to solve the existing problem." "A very important point is that the Romanian Orthodox Church recognizes the "right to autocephaly" to Ukraine even if it falls short of recognizing the new Church. The solution of the crisis could be, for the Romanian Orthodox Church, a Synaxis of all Primates of Orthodox Churches only if the dialogue between Moscow and Constantinople does not bring fruits (at the moment there is no dialogue between the two Sees). The real issue for the Romanian Orthodox Church (in order to recognize the new Church) seems to be the 127 Romanian Orthodox parishes in Ukraine, especially in Northern Bukovina, ${ }^{6}$ which are under the jurisdiction of the Moscow Patriarchate. The Romanian Orthodox Church believes "a real consultation is needed with these Romanian Orthodox people, who are concerned with preserving their ethnic and linguistic identity." Obviously, the Romanian Orthodox Church is worried about the identity of these parishes so "it is necessary to obtain written assurances from Ukrainian ecclesiastical and state authorities that the ethnic and linguistic identity of these Romanians will be respected, and that these Romanian Orthodox will have the possibility to organise themselves within a Romanian Orthodox Vicariate and to be able to

\footnotetext{
4 "Holy Synod examines Ukrainian Ecclesiastical issue", https://basilica.ro/en/holy-synod- examines-ukrainian-ecclesiastical-issue-at-first-2019-working-session/, viewed on March 15, 2019.

5 Ibidem.

${ }^{6}$ Between the two World Wars, Bukovina was part of the Kingdom of Romania.

7 "Holy Synod examines Ukrainian Ecclesiastical issue".
} 
cultivate spiritual relations with the Romanian Patriarchate, in order to be supported by sending liturgical and theological books in their mother tongue, that is, in the Romanian language." It was noted that a Ukrainian Orthodox Vicariate has been operating in Romania since 1990. How can the Romanian Orthodox Church gain written assurances on this issue from the Orthodox Church of Ukraine when the Romanian Orthodox Church does not have a dialogue with the new Church and does not recognize it? There is no mention though of any desire of the Romanian Orthodox Church to re-establish its structures in northern Bucovina as it did in Bessarabia (The Republic of Moldova), but the discussion seems to be only of a Romanian Orthodox Vicariate which would have spiritual relations with the Romanian Patriarchate. As other Orthodox Churches, the Romanian Orthodox Church asks the Ecumenical Patriarchate to clarify the problem of the non-canonical hierarchs and priests in the West, who belonged to the former Kiev Patriarchate. The issue of the validity of ordinations is just a question of clarification from the Ecumenical Patriarchate and the nuance could be noticed because other Orthodox Churches simply do not recognize those ordinations. The final position of the Romanian Orthodox Church will be expressed only after having an answer to all these issues. If the Orthodox Church of Ukraine expected a quick recognition from Romania this is obviously not the case even if the Romanian Orthodox Church is considered close to the Ecumenical Patriarchate and less close to Moscow for historical reasons.

On March 29, 2019, the official internet portal of the Albanian Orthodox Church published the text of a letter written by Anastasios, Archbishop of Tirana and All Albania, to the Ecumenical Patriarch. His Beatitude, Anastasios, gave special attention to the problem of the apostolic succession of the "Ukrainian schismatic leaders and their followers" admitted to communion with the Patriarchate of Constantinople. This Letter underlines that the Albanian Orthodox Church "did not express any doubt as to the right and responsibility of the Ecumenical Patriarchate to grant Autocephaly, whenever this is called for by the circumstances." 10 There seems to be though a clear worry about the crucial subject of the ordination of bishops of Apostolic Succession. The Albanian Orthodox Church speaks clearly about the ordinations performed by the former Metropolitan of Kyiv, Filaret, who was "defrocked,

\footnotetext{
8 Ibidem.

9 Idbiem.

${ }^{10}$ Archbishop Anastasios of Tirana, On the Ukrainian Ecclesiastical Question. $2^{\text {nd }}$ Reply. See the entire letter: http://orthodoxalbania.net/index.php/en-us/lajme-3/blog/6884-on-the-ukrainian-ecclesiastical-question-2nd-reply-speaking-the-truth-in-love, viewed on March 15, 2019.
} 
has been aphorised and anathematised" 11 by Moscow. After Constantinople restored him in the communion of the Church were all his ordinations (from the period between the Moscow decisions and the reverse of those decisions by Constantinople) to be considered valid? The Albanian Orthodox Church seems to be rather in doubt than necessarily considering the invalidity. In order to preserve Orthodox unity, the Albanian Church believes a Panorthodox Consultation of some kind, aiming primarily at the spiritual support of all the Orthodox faithful in the Ukraine and, above all, at the safeguarding of Orthodox cohesion would be needed. It is interesting that the Albanian Church does not speak necessarily about the Sinaxis of Orthodox Primates. And the privilege of convening a Panorthodox Consultation undoubtedly belongs to the Ecumenical Patriarch, ${ }^{12}$ according to the letter. The Albanian Orthodox Church remains close to Constantinople, but does not recognize at the moment the new Church in Ukraine.

The Polish Autocephalous Orthodox Church is known as not very favourable to the new Church of Ukraine even if it theoretically does not oppose the idea of autocephaly of Orthodoxy in Ukraine. For this Orthodox Church, the granting of autocephaly by Constantinople was "a non-canonical act that violates Eucharistic and inter-Orthodox unity", ${ }^{13}$ very strong words indeed from a Church that became autocephalous because of a Tomos from Constantinople.

While the Greek and Cyprus Orthodox Churches would be considered closer to Constantinople, none of them has yet recognized the new Church in Ukraine. The same could be said about the Jerusalem Patriarchate. The Serbian Orthodox Church opposes openly the Tomos and seems not to have any intention even to take into consideration the recognition of the new Orthodox Church of Ukraine into consideration.

The different structures in the western world where Orthodox Churches were together in advisory bodies (like the Conference of Orthodox Bishops in Germany) experience now a real difficulty because the Russian Orthodox Bishops would not accept to continue to be part of them if leaded by Constantinople Hierarchs. Some parishes there were under Constantinople in Western Europe, but were initially Russian asked to be under Moscow after the ecumenical Patriarchate abolished the ecclesiastical structure that had been only for the Russians after the Russian Revolution. The crisis between Moscow and Constantinople based on the Ukrainian autocephaly affects now the situation in Western Europe, too.

\footnotetext{
11 Ibidem.

12 Ibidem.

13 See: http://orthochristian.com/117295.html, viewed on March 16, 2019.
} 


\section{Moscow, Kyiv and the Issue of Religious Freedom}

While the debatable religious freedom in Eastern Ukraine and Crimea (not under Ukrainian control) is more known to the world and the different Churches (Ukrainian Church of Ukraine, Ukrainian Greek-Catholic Church) and religions speak about restrictions if not open persecution, the Moscow Patriarchate, with a Statement on the 26th of February speaks about the "dramatic aggravation of the situation of the Ukrainian Orthodox Church." "14 The Russian Orthodox Church sees the situation "worsened ever more considerably the inter-confessional relations. Causing particular concern is a gross interference of the state authorities of Ukraine in the internal church life, as well as politicians' attempts to use the Church in their opportunistic interests. By doing so they violate the fundamental human rights and freedoms secured, for instance, by the Constitution of Ukraine." 15 The issue of the name of the Orthodox Church under Moscow jurisdiction in Ukraine is clearly raised because the Ukrainian Parliament issued a new law at the end of December (ratified by the President) which could bring a change in the name of the Ukrainian Orthodox ChurchMoscow Patriarchate to a name that would mention the name Russian ("Russian Orthodox Church in Ukraine"?). It is certainly very rare in a democratic country to see an intervention of the state regarding the official name of a religious denomination. However, there were very few international reactions to this law coming from governments or other political bodies. The Russian Orthodox Church is also worried about the legalizing of the practice of seizing its church buildings and monasteries. And it speaks openly about the civil Ukrainian authorities that would want "to liquidate the Ukrainian Orthodox Church. In most cases, seizures of church buildings take place in spite of religious communities' decisions to remain in the canonical Church. A religious community's decision is being replaced by a vote of a public gathering of the citizens who by no means are always members of a parish of the Ukrainian Orthodox Church. Minutes of such gatherings receive immediate approval from the authorities, and after that a church building is seized with the assistance of security and law enforcement units." ${ }^{16}$ Hard to know how much truth is in this, but that there are tensions in different places between the faithful of the two Orthodox jurisdictions is beyond doubt.

14 Department for External Church Relations, Aggravation of the situation of the Ukrainian Orthodox Church ascertained in the UN, https://mospat.ru/en/2019/03/14/news171484/, viewed on March 16, 2019.

15 Ibidem.

16 Ibidem. 
During an Organization for Security and Co-operation in Europe meeting on April 1, Archbishop Yevstratiy (Zorya), an Orthodox Church of Ukraine representative at the European institutions, said that the Moscow Patriarchate is exerting informational and legal pressure to impede "the free choice of denominations by Ukrainians." But he reiterates that "the Ukrainian Church stands for the right of every religious community to make their unimpeded choice under the law to which religious centre it wishes to be subordinated. This complies with the general right to freedom of religion and belief. We oppose violence and have repeatedly condemned all appeals to violence in matters concerning the Church. We are open to a constructive dialogue with all the parties involved, including the OSCE." 17

The question of the property of churches in Ukraine is rather complex for different reasons: many churches are officially in the property of the state, the non-intervention of local authorities is many times rather a wishful thinking, and it is not obvious who can decide (the practicing members of a Community, the nominal members of the Community, the priest).

After a few months from the creation of the new Church, the majority of the Orthodox parishes in Ukraine remain under the Moscow jurisdiction (with 100 Bishops) even if it is not clear which one of the two jurisdictions has more believers. For the moment there is no communion between the two Churches and no easy solution to arrive at that.

\section{Catholic-Orthodox Dialogue after the Tomos}

Because of the Ukrainian issue, the Moscow Patriarchate is not represented for the moment in the International Orthodox-Catholic Theological Commission of Dialogue and the ecumenical bodies where the different Orthodox Churches are represented in different countries experience the same.

The Ukrainian Greek-Catholic Church announced the desire to organize a prayer of its Church in the historic St. Sophia in Kyiv because the Greek-Catholics consider that "our Kyiv Christian heritage-is a common ground where all the heirs can meet, be present." The head of the Ukrainian Greek-Catholic Church made a request on April 7 to celebrate liturgy in the cathedral. The request was not welcomed by the Orthodox Church of Ukraine even if the Cathedral belongs officially to the state. The dialogue between the Ukrainian Greek-Catholic Church and the Orthodox Church of Ukraine remains though a reality in the local complex religious reality.

Cardinal Kurt Koch, president of the Vatican's Pontifical Council for Promoting Christian Unity, visited Moscow on Feb. 12 for the third anni-

17 See: https://risu.org.ua/en/index/all_news/community/religion_and_policy/75286, viewed on March 16, 2019. 
versary of the Pope's historic meeting with Patriarch Kirill in Cuba, and he assured Patriarch Kirill's foreign relations director, Metropolitan Hilarion Alfeyev, that efforts would continue to forge inter-church links. The Holy See continues to promote ecumenical relations both with Constantinople and Moscow and does not intervene in any way in the question of Orthodox autocephaly in Ukraine. ${ }^{18}$

The question of the Ukrainian autocephaly remains a sensitive issue among the Orthodox Churches, but has ecumenical consequences and presents different challenges regarding religious freedom. Those who believed that the situation would become less complicated after the Tomos have to recognize they were not realistic enough.

Christian unity has a long path, but now the Orthodox Churches try to rebuild bridges between themselves. There is a need for more prayer, but also for more dialogue and reconciliation. In a world where secularism is widespread in society, Christians need to be more united in order to be credible and authentic witnesses of the Gospel.

18 See: https://www.ncronline.org/news/people/new-ukraine-church-endures-inter-orthodoxfeud-offers-catholics-hope, viewed on March 14, 2019. 